\title{
DESKRIPSI KEMAMPUAN PENALARAN SISWA DALAM PEMECAHAN MASALAH MATEMATIKA PADA MATERI ARITMATIKA SOSIAL
}

\author{
Elfrida Ardhiyanti ${ }^{1}$, Sutriyono ${ }^{2}$, Fika Widya Pratama ${ }^{3}$ \\ 1,2,3 Program Studi Pendidikan Matematika FKIP Universitas Kristen Satya Wacana \\ elfridaardhiyant@gmail.com
}

\begin{abstract}
This research is a descriptive qualitative study that aims to describe students's reasoning abilities in solving mathematical problems in social arithmetic material. Reasoning ability can be identified by completing mathematical problem solving in social arithmetic material made based on reasoning indicators in the study, namely (1) submitting allegations, (2) manipulating, (3) drawing conclusions, compiling evidence, giving reasons and (4) interesting conclusion of all statements. The selection of subjects in this study used a purposive sampling technique consisting of 1 student with high mathematical abilities, 1 student with moderate mathematical abilities, and 1 student with low mathematics ability seventh grade in SMP Negeri 7 Salatiga in the 2017/2018 school year. Methods of data collection with documentation methods, test methods and interviews with through 3 steps of analysis, namely data reduction, data presentation, and conclusion. The results of this study indicate that students with high mathematical abilities can meet the indicators to submit suspicions and manipulate them. Students with moderate mathematical abilities can fulfill all four indicators. While students with low mathematical abilities cannot fully all four indicators. This research is expected to contribute to teachers about the mathematical reasoning abilities of junior high school students in solving problems in social arithmetic material and for students to be able to improve students' mathematical reasoning abilities.
\end{abstract}

Keywords: Reasoning Ability, Mathematical Problems, Social Arithmetic, Mathematical Ability

\begin{abstract}
Abstrak
Penelitian ini merupakan penelitian kualitatif deskriptif yang bertujuan untuk mendeskripsikan kemampuan penalaran siswa dalam pemecahan masalah matematika pada materi aritmatika sosial. Kemampuan penalaran dapat diidentifikasi dengan menyelesaikan soal pemecahan masalah matematika pada materi aritmatika sosial yang dibuat berdasarkan indikator penalaran dalam penelitian yaitu (1) mengajukan dugaan, (2) melakukan manipulasi, (3) menarik kesimpulan, menyusun bukti, memberikan alasan dan (4) menarik kesimpulan atas semua pernyataan. Pemilihan subjek dalam penelitian ini menggunakan teknik purposive sampling yang terdiri dari 1 siswa berkemampuan matematika tinggi, 1 siswa berkemampuan matematika sedang, dan 1 siswa berkemampuan matematika rendah kelas VIII di SMP Negeri 7 Salatiga tahun ajaran 2017/2018. Metode pengumpulan data dengan metode dokumentasi, metode tes dan wawancara dengan melalui 3 langkah analisis yaitu reduksi data, penyajian data, dan penarikan kesimpulan. Hasil penelitian ini menunjukkan siswa berkemampuan matematika tinggi dapat memenuhi indikator untuk mengajukan dugaan dan melakukan manipulasi saja. Siswa berkemampuan matematika sedang dapat memenuhi keempat indikator. Sedangkan siswa berkemampuan matematika rendah tidak dapat memenuhi keempat indikator. Penelitian ini diharapkan dapat memberi sumbangan bagi guru tentang kemampuan penalaran matematika siswa SMP dalam menyelesaikan soal pada materi aritmatika sosial dan bagi siswa untuk lebih dapat meningkatkan kemampuan penalaran matematika siswa.
\end{abstract}

Kata Kunci: Kemampuan Penalaran, Masalah Matematika, Aritmatika Sosial, Kemampuan Matematika

Menurut standar isi pada Permendikbud nomor 21 tahun 2016 menyatakan bahwa kompetensi inti untuk tingkat pendidikan menengah yaitu menunjukkan keterampilan menalar secara kreatif, produktif, kritis, mandiri, kolaboratif, dan komunikatif dalam ranah konkret dan abstrak. Oleh karena itu, dalam pembelajaran matematika perlu dilatih kemampuan penalaran siswa. Hal itu juga tercantum 
dalam salah satu tujuan matematika yang tertuang dalam Permendiknas nomor 22 tahun 2006 yaitu menggunakan penalaran pada pola dan sifat, melakukan manipulasi matematika dalam membuat generalisasi, menyusun bukti, atau menjelaskan gagasan dan pernyataan matematika. Berdasarkan tujuan pembelajaran matematika maka kemampuan penalaran memiliki peranan yang penting dalam pembelajaran matematika.

Sejalan dengan hal tersebut, pentingnya penalaran dalam pembelajaran matematika didukung oleh beberapa peneliti. Sumarmo (Hendriana, 2017: 25) menjelaskan penalaran menjadi penting dalam matematika karena matematika memuat proses yang aktif, dinamis, dan generatif yang dikerjakan oleh pelaku dan pengguna matematika. Penalaran dalam matematika dapat membantu individu tidak sekedar mengingat fakta, aturan, dan langkah penyelesaian-penyelesaian masalah, tetapi menggunakan keterampilan bernalarnya dalam melakukan pendugaan atas dasar pengalamanya sehingga yang bersangkutan akan memperoleh pemahaman konsep matematika yang saling berkaitan dan belajar secara bermakna (Baroody dan Nasution dalam Hendriana, 2017: 25).

Penalaran menurut Suriasumantri (2009: 42) penalaran adalah suatu proses berpikir dalam menarik kesimpulan yang berupa pengetahuan. Menurut Keraf (Hendriana, 2017: 26) penalaran adalah proses berpikir manusia yang berusaha menghubung-hubungkan suatu fakta-fakta yang diketahui untuk menarik kesimpulan. Menurut Meicahyati (2018) Penalaran yaitu proses berfikir yang dilakukan dengan satu cara untuk menarik kesimpulan Menurut Komang (2015) menjelaskan bahwa penalaran sangat diperlukan siswa dalam proses memecahkan masalah matematika. Sejalan dengan pendapat berbagai sumber, maka penalaran merupakan proses berpikir seseorang untuk merumuskan kesimpulan berdasarkan fakta-fakta yang ditemukan sehingga dari merumuskan kesimpulan tersebut akan memperoleh atau memutuskan suatu kesimpulan yang akan dipakai dalam suatu masalah serta penalaran penting digunakan dalam proses pemecahan masalah.

Kemampuan penalaran siswa dalam memecahkan masalah berbeda-beda, hal ini sejalan dengan temuan beberapa peneliti. Penelitian (Pawesti, 2017) yang menyatakan bahwa kemampuan penalaran siswa pada gaya belajar auditori memiliki tingkat kemampuan penalaran sedang, gaya belajar visual auditori memiliki tingkat kemampuan penalaran sedang, serta pada gaya belajar visual kinestetik, auditori kinetetik, visual auditori kinestetik menunjukkan pada tingkat kemampuan penalaran sedang. Penelitian Yenni (2016) menjelaskan 36\% siswa dapat menggunakan penalarannya sehingga memperoleh nilai diatas KKM sisanya 64\% mendapat nilai dibawah KKM dikarenakan tidak dapat menggunakan penalarannnya dalam memecahkan masalah terkhusus pada siswa laki-laki yang belum dapat menggunakan penalarannya dengan maksimal. Oleh karena itu, penalaran siswa berperan penting dalam memecahkan pemecahan masalah.

Kegiatan belajar perlu mengutamakan pemecahan masalah karena dengan sering menghadapi pemasalahan matematika siswa akan terdorong untuk menggunakan nalarnya sehingga penalaran siswa terlatih (Suciati, 2015). Salah satu yang dapat meningkatkan kemampuan pemecahan masalah siswa ialah perangkat pembelajaran berbasis masalah. Pembelajaran berbasis masalah merupakan 
model pembelajaran dimana masalah-masalah yang terjadi di dunia nyata digunakan sebagai konteks bagi siswa untuk belajar materi-materi pembelajaran (Prasetyo, 2017). Oleh karena itu perangkat pembelajaran berbasis masalah dapat digunakan untuk meningkatkan kemampuan pemecahan masalah, salah satu materi yang termasuk dalam pemecahan masalah dan dapat melatih penalaran siswa adalah materi aritmatika sosial. Menurut Andayani (2019) menyatakan bahwa masih banyak siswa yang mengalami kesulitan dalam memahami kesulitan dalam memahami masalah pada materi aritmatika sosial. Berdasarkan latar belakang penelitian ini, maka tujuan penelitian ini untuk mengetahui bagaimana kemampuan penalaran siswa pada pembelajaran matematika berdasarkan tingkat hasil belajar matematika tinggi, sedang, dan rendah.

\section{Metode Penelitian}

Jenis penelitian ini adalah kualitatif deskriptif. Penelitian ini bertujuan untuk mendeskripsikan kemampuan penalaran siswa berkemampuan tinggi, sedang, dan rendah pada pemecahan masalah matematika pada materi aritmatika sosial. Subjek penelitian ini adalah 3 siswa SMP Negeri 7 Salatiga yang mewakili kategori siswa dengan tingkat belajar matematika tinggi, sedang, rendah. Subjek dipilih menggunakan teknik purposive sampling dan berdasarkan kriteria yang ditentukan oleh peneliti serta hasil diskusi dengan guru matematika SMP Negeri 7 Salatiga. Pengkategorian tingkat belajar siswa ditentukan berdasarkan hasil Penilaian Akhir Semester (PAS) kelas VII tahun ajaran 2017/2018. Berikut pada tabel 1 menunjukkan tingkat kemampuan subjek yang dipilih.

\section{Tabel 1.}

Subjek Penelitian

\begin{tabular}{lllll} 
Tingkat & Kemampuan & Jumlah & Interval & Data Subjek \\
\cline { 5 - 5 } Siswa & Siswa & Nilai & Nilai PAS & Inisial \\
\hline Tinggi & 22 & $90-77$ & 90 & JC \\
\hline Sedang & 165 & $76-63$ & 70 & SB \\
\hline Rendah & 45 & $62-49$ & 60 & NA \\
\hline
\end{tabular}

Instrumen dalam penelitian ini adalah peneliti sendiri sebagai instrumen utama dan instrumen pendukung berupa soal tes untuk mengukur kemampuan menalaran siswa pada materi aritmatika sosial. Soal tes kemampuan penalaran yang digunakan berbentuk uraian yang sudah divalidasi oleh 2 dosen pendidikan matematika UKSW dan 1 guru matematika SMP Negeri 7 Salatiga. Setelah soal dikerjakan dilakukan wawancara kepada subjek sebagai uji keabsahan data, selajutnya setalah data terkumpul kemudian diakukan analisis. Analisis data mengacu pada model Miles dan Huberman (Sugiyono, 2014: 337) ada 3 yaitu: reduksi data, penyajian data, dan penarikan kesimpulan (verification). 


\section{HASIL DAN PEMBAHASAN}

Penelitian ini dilakukan pada 14 September 2018 di perpustakaan SMP Negeri 7 Salatiga. Ketiga subjek bersama-sama mengerjakan soal tes kemampuan penalaran kemudian dilakukan wawancara satu persatu agar mendapatkan data yang akurat. Berikut hasil yang diperoleh dan analisis dari ketiga subjek:

\section{Analisis Soal Nomor 1}

Soal tes yang menggunakan kemampuan penalaran nomor 1 sebagai berikut: Toko buku "Tris" menyediakan beberapa alat tulis yaitu bolpoin, penggaris, buku petak, penghapus, dan buku tulis dengan masing-masing harga satuannya Rp2.000,00, Rp1.700,00, Rp3.000,00, Rp900,00, Rp3.500,00. Jika ibu memiliki uang sebesar Rp30.000,00 dan ingin membelanjakan uang tersebut untuk membeli 3 jenis alat tulis dan salah satunya Ibu membeli $\frac{1}{2}$ kodi bolpoin, maka dua jenis alat tulis apa saja yang mungkin ibu beli dengan sisa uang yang ada? Jelaskan

\section{Subjek Kemampuan Matematika Tinggi (JC)}

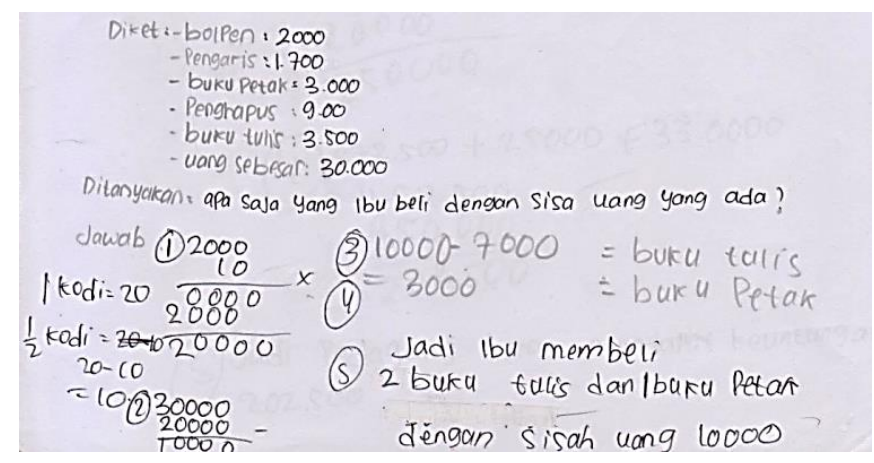

Gambar 1. Hasil Pekerjaan Subjek pada Soal Nomor 1

Berdasarkan hasil tes dan wawancara subjek JC dapat menyelesaikan soal pemecahan masalah yang diberikan terlihat pada gambar 1. Subjek JC mampu mengajukan dugaan dengan cara menyebutkan secara runtut dan detail informasi-informasi yang diketahui dan ditanya. Subjek JC mampu melakukan manipulasi karena subjek mampu menjabarkan cara atau langkah yang digunakan dan dapat menjelaskan secara lisan cara yang digunakan. Subjek JC juga mampu menjelaskan kesimpulan, bukti dan memberikan alasan atas pernyataan yang diberikannya melalui penjelasan subjek JC yang menjelaskan secara rinci total harga barang yang didapat ibu. Subjek JC mampu menarik kesimpulan atas seluruh hasil pekerjaannya, subjek JC mampu menuliskannya dan menjelaskannya. 


\section{Subjek Kemampuan Matematika Sedang (SB)}

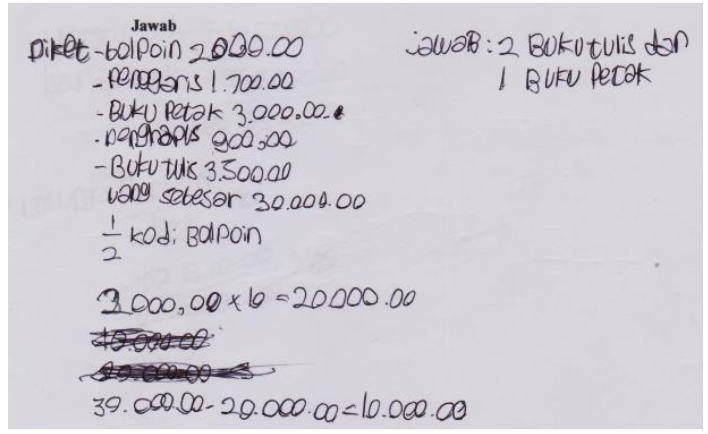

Gambar 2. Hasil Pekerjaan Subjek pada Soal Nomor 1

Berdasarkan hasil tes dan wawancara subjek SB dapat menyelesaikan soal pemecahan masalah yang diberikan. Subjek SB juga dapat mengajukan dugaan dengan cara menyebutkan secara runtut dan detail apa yang diketahui dan ditanya. Subjek SB mampu melakukan manipulasi dengan mengubah satuan kodi menjadi buah dan dapat menjelaskan melalui wawancara yang dilakukan serta subjek SB mampu menuliskan langkah-langkah penyelesaian dengan baik. Subjek SB juga dapat menjelaskan kesimpulan, bukti dan memberikan alasan atas pernyataan yang diberikannya dengan menjelaskan harga dan alat tulis apa saja yang didapat oleh ibu. Subjek SB mampu menarik kesimpulan atas seluruh hasil pekerjaannya yang sudah ditulisnya dengan menyebutkan sisa uang ibu dan alat tulis yang didapat ibu.

\section{Subjek Kemampuan Matematika Rendah (NA)}

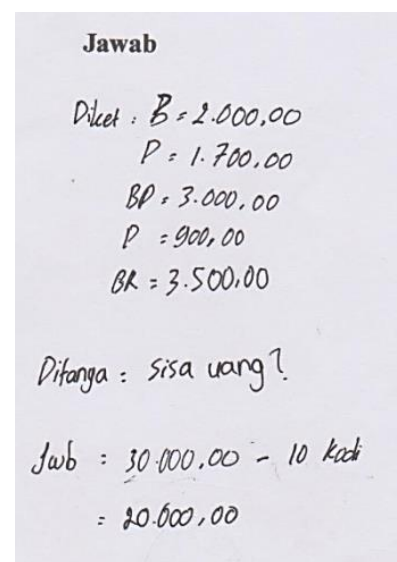

Gambar 3. Hasil Pekerjaan Subjek pada Soal Nomor 1

Berdasarkan hasil tes dan wawancara subjek NA tidak dapat menyelesaikan soal pemecahan masalah yang diberikan. Subjek NA tidak dapat memenuhi indikator mengajukan dugaan karena tidak dapat menyebutkan secara detail apa yang ditannya. Subjek NA tidak dapat melakukan manipulasi karena tidak dapat menyelesaikan masalah secara terstuktur, subjek NA terlihat asal-asalan dalam menuliskan hasil jawaban. Terlihat dari hasil jawaban subjek NA tidak mampu menuliskan dan menjelaskan kesimpulan, bukti dan memberikan alasan atas pernyataan yang diberikannya. Subjek 
NA tidak mampu menarik kesimpulan atas seluruh hasil pekerjaannya yang sudah ditulisnya dengan baik

\section{Analisis Soal Nomor 2}

Soal tes yang menggunakan kemampuan penalaran untuk nomor 1 sebagai berikut: Seorang pedagang $\mathrm{b}$ eras membeli 1 kuintal beras dengan harga Rp950.000,00. Pedagang tersebut menjual 45 $\mathrm{kg}$ beras dengan harga Rp10.500,00/kg, saat musim panen tiba pedagang tersebut menjual $25 \mathrm{~kg}$ beras dengan harga Rp10.000,00/kg, karena harga beras di pasar naik maka pedagang tersebut menjual sisanya dengan harga Rp11.000,00/kg. Berapa persentase keuntungan atau kerugian yang didapat oleh pedagang?

\section{Subjek Kemampuan Matematika Tinggi (JC)}

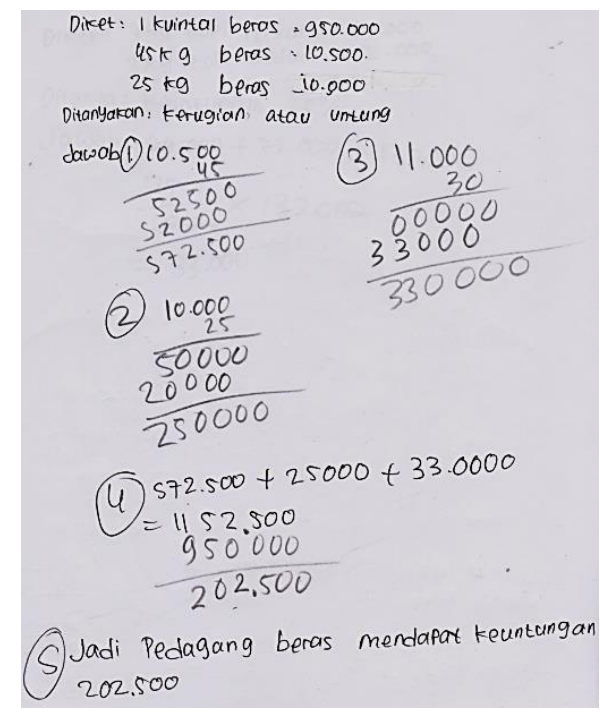

Gambar 4. Hasil Pekerjaan Subjek pada Soal Nomor 2

Berdasarkan hasil tes dan wawancara subjek JC dapat menyelesaikan soal pemecahan masalah yang diberikan. Subjek JC mampu mengajukan dugaan dengan cara menyebutkan secara runtut dan detail apa yang diketahui dan ditanya serta subjek JC mampu menalar dengan cara membayangkan bahwa subjek JC menjadi seorang pedagang bolpoin. Subjek JC mampu melakukan manipulasi untuk menyelesaikan masalah dengan menuliskan dan menjelaskan langkah-langkah yang ia pakai untuk menjawab permasalahan yang diberikan, hanya saja subjek JC tidak teliti dalam perhitungan. Tetapi subjek JC tidak mampu menjelaskan kesimpulan, memberikan bukti dan memberikan alasan atas pernyataan yang diberikannya karena subjek tidak mampu menjawab persentase keuntungan yang dicari oleh pedagang. Subjek JC tidak mampu menarik kesimpulan atas seluruh hasil pekerjaannya, subjek hanya menuliskan kuntungan yang didapat oleh pedagang. 
Subjek Kemampuan Matematika Sedang (SB)

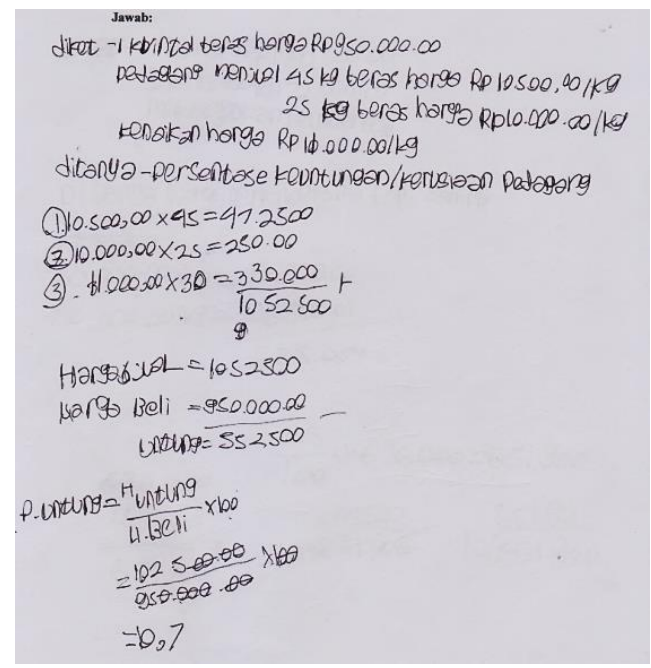

Gambar 5. Hasil Pekerjaan Subjek pada Soal Nomor 2

Berdasarkan hasil tes dan wawancara subjek SB dapat menyelesaikan soal pemecahan masalah yang diberikan mengenai persentase keuntungan atau kerugian yang akan didapat oleh pedagang beras. Subjek SB mampu mencapai semua indikator penalaran. Subjek SB mampu mengajukan dugaan dengan cara menyebutkan apa yang diketahui dan ditanya dengan baik. Subjek SB juga dapat melakukan manipulasi untuk menyelesaikan masalah dengan baik dan secara runtut, hanya saja subjek SB kurang menuliskan keterangan dalam hasil penyelesaiannya. Subjek SB juga mampu menjelaskan kesimpulan, memberikan bukti dan memberikan alasan dengan menuliskan keuntungan dan persntase keuntungan, hanya saja subjek SB masih belum tepat dalam perhitungannya. Subjek SB juga mampu menarik kesimpulan atas seluruh hasil pekerjaannya yang sudah ditulisnya.

\section{Subjek Kemampuan Matematika Rendah (NA)}

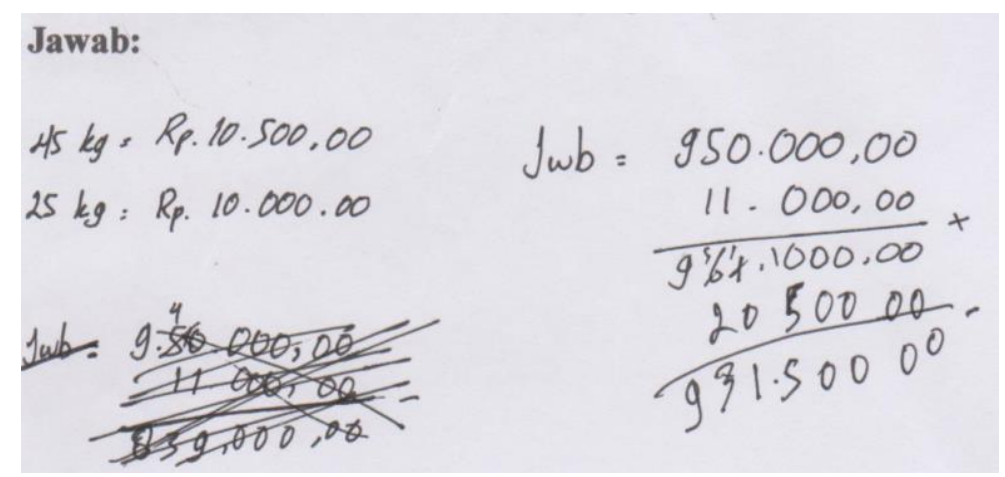

Gambar 6. Hasil Pekerjaan Subjek pada Soal Nomor 2

Berdasarkan hasil tes dan wawancara subjek NA tidak dapat menyelesaikan soal pemecahan masalah yang diberikan. Subjek NA tidak mampu mencapai semua indikator penalaran. Subjek NA 
tidak dapat mengajukan dugaan dengan cara menyebutkan dan menuliskan informasi-informasi apa yang diketahui dan ditanya dalam soal. Subjek NA tidak dapat melakukan manipulasi untuk menyelesaikan masalah dengan baik karena perhitungan yang subjek NA tuliskan tidak sesuai serta subjek NA tidak dapat menuliskan dengan jelas langkah-lagkah yang ia tuliskan. Subjek NA juga tidak mampu menjelaskan kesimpulan, memberikan bukti dan memberikan alasan atas pernyataan yang diberikannya karena subjek NA tidak dapat menuliskan dan menjelaskan. Subjek NA tidak mampu menarik kesimpulan atas seluruh hasil pekerjaannya yang sudah ditulisnya.

\section{Analisis Soal Nomor 3}

Soal tes yang menggunakan kemampuan penalaran untuk nomor 1 sebagai berikut: Pak Bembi membeli $7 \mathrm{~kg}$ kopi jenis pertama dengan harga Rp60.000,00/kg dan $3 \mathrm{~kg}$ kopi jenis kedua seharga Rp72.000,00/kg. Kemudian pak Bembi mencampur kedua jenis kopi tersebut dan akan menjualnya lagi untuk mendapatkan keuntungan sebesar 25\%. Berapa rupiah pak Bembi harus menjual perkilogram kopi campur tersebut agar memperoleh keuntungan sebesar $25 \%$ dari harga belinya?

\section{Subjek Kemampuan Matematika Tinggi (JC)}

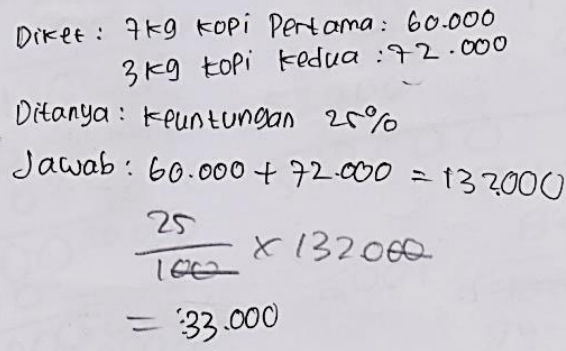

Gambar 7. Hasil Pekerjaan Subjek pada Soal Nomor 3

Berdasarkan hasil tes dan wawancara subjek JC tidak dapat menyelesaikan soal pemecahan masalah yang diberikan mengenai harga jual kopi campur agar pak bembi dapat memperoleh keuntungan 25\%. Subjek JC hanya mampu memenuhi satu indikator penalaran. Subjek JC dapat mengajukan dugaan dengan cara menyebutkan dengan baik apa yang diketahui dan ditanya. Subjek JC tidak mampu melakukan karena subjek JC tidak dapat mengkalikan harga kopi perkilogramnya dengan jumlah kopi yang sudah ditentukan. Subjek JC juga tidak memenuhi indikator menarik kesimpulan, memberikan bukti dan memberikan alasan karena tidak dapat menuliskan harga jual kopi agar pedagang memberoleh $25 \%$. Pada indikator menarik kesimpulan atas penyataan yang dibuat subjek JC tidak mampu menarik kesimpulan atas seluruh hasil pekerjaannya yang sudah ditulisnya. 


\section{Subjek Kemampuan Matematika Sedang (SB)}

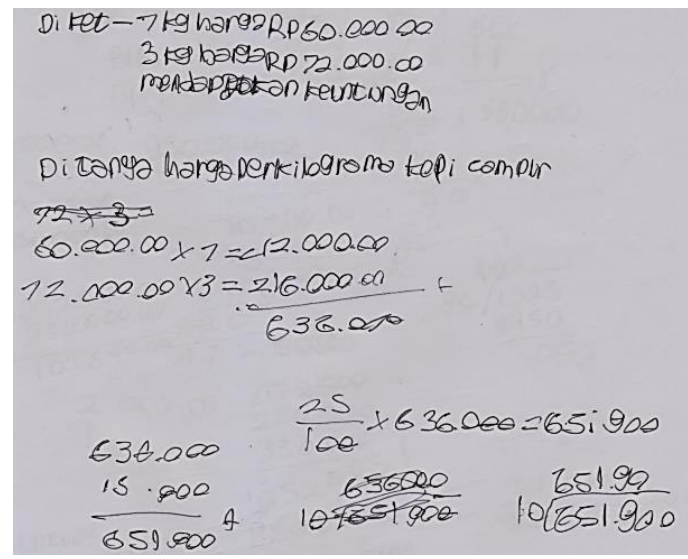

Gambar 8. Hasil Pekerjaan Subjek pada Soal Nomor 3

Berdasarkan hasil tes dan wawancara subjek SB dapat menyelesaikan soal pemecahan masalah yang diberikan dengan baik mengenai harga jual kopi campur agar pak bembi dapat memperoleh keuntungan 25\%. Subjek SB mampu memenuhi semua indikator penalaran. Subjek SB dapat mengajukan dugaan dengan cara menyebutkan dengan baik apa yang diketahui dan ditanya. Pada indikator melakukan manipulasi subjek SB dapat memenuhinya karena subjek SB dapat menjelaskan cara penyelesaian yang digunakan. Subjek SB dapat memenuhi menjelaskan kesimpulan, memberikan bukti dan memberikan alasan karena subjek SB mampu menjelaskan cara yang dipakai untuk mencari harga jual agar pedagang mendapat keuntungan 25\%. Subjek SB mampu melakukan penarikan keimpulan akhir pada hasil pekerjaannya karena subjek SB dapat menyimpulkan harga jual agar pedagang kopi mendapat keuntungan $25 \%$.

\section{Subjek Kemampuan Matematika Rendah (NA)}

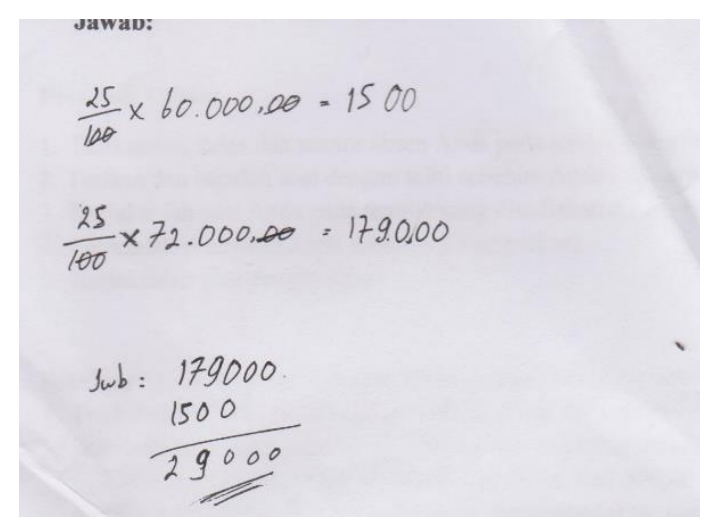

Gambar 8. Hasil Pekerjaan Subjek pada Soal Nomor 3

Berdasarkan hasil tes dan wawancara subjek NA tidak dapat menyelesaikan soal pemecahan masalah yang diberikan. Subjek NA tidak mampu memenuhi semua indikator penalaran. Subjek NA tidak dapat mengajukan dugaan dengan cara menyebutkan dengan lengkap apa yang diketahui dan 
ditanya. Subjek NA tidak mampu melakukan manipulasi karena subjek NA tidak dapat menjelaskan cara penyelesaian yang digunakan. Subjek NA tidak dapat memenuhi indikator menjelaskan kesimpulan, memberikan bukti dan memberikan alasan karena langkah yang digunakan untuk mengerjakan kurang tepat serta subjek NA tidak mampu menjelaskan pada saat diwawancarai. Sujuga tidak mampu dalam menarik kesmipulan atas penyataan yang dibuat, subjek NA tidak dapat menuliskan dan menjelaskan kesimpulan.

\section{PEMBAHASAN}

Berdasarkan hasil analisis yang telah dibuat, maka akan dilakukan pembahasan untuk tiap indikator kemampuan penalaran pada siswa berkemampuan tinggi, sedang dan rendah.

\section{Indikator Mengajukan Dugaan}

Berdasarkan data yang diperoleh melalui hasil tes dan wawancara menunjukkan bahwa subjek berkemampuan matematika tinggi dan subjek berkemampuan matematika sedang mampu mengajukan dugaan dengan baik. subjek berkemampuan matematika tinggi dan subjek berkemampuan matematika sedang mampu menuliskan dengan baik informasi-informasi yang diketahui dan apa yang ditanyakan pada soal yang diberikan. subjek berkemampuan matematika tinggi dan subjek berkemampuan matematika sedang mampu menjabarkan informasi apa saja yang didapat dari soal yang diberikan baik secara tertulis ataupun secara lisan, berbeda dengan subjek berkemampuan matematika rendah. Subjek berkemampuan matematika rendah tidak dapat mengajukan dugaan dengan baik pada permasalahan yang diberikan, terlihat bahwa ia tidak mampu menuliskan informasi-informasi yang ada pada soal serta tidak mampu menjelaskan secara lisan. Hal ini sejalan dengan penelitian Nafi'ah (2015) menyatakan bahwa siswa yang mampu mengajukan dugaan dapat dilihat saat menuliskan apa yang diketahui dan apa yang ditanyakan ketika menyelesaikan soal cerita. penelitian ini juga sejalan dengan penelitian Mualifah (2014) yag menyatakan bahwa siswa yang berkemampuan matematika tinggi berhasil melakukan dugaan dengan dapat menyebutkan informasi-informasi yang tersedia dalam soal, untuk siswa yang berkemapuan matematika rendah tidak dapat menyusun dugaan kerena tidak dapat menyusu informasi sehingga tidak dapat menyelesaiakn masalah. Menurut penelitian Zaenab (2015) siswa yang mendapat predikat baik dan siswa memiliki predikat sedang pada pelajaran matematika dikelas siswa dapat mengajukan dugaan apa yang diketahui dan apa yang ditanya dengan benar.

\section{Indikator Melakukan Manipulasi}

Berdasarkan data hasil analisis yang sudah dipaparkan sebelumnya, subjek berkemampuan matematika tinggi dan subjek berkemampuan matematika sedang mampu melakukan manipulasi untuk menyelesaikan permasalahan yang diberikan dengan baik, berbeda dengan subjek berkemampuan matematika rendah yang tidak mampu melakukan manipulasi dengan baik. Hal ini terlihat dari cara subjek berkemampuan matematika tinggi dan subjek berkemampuan matematika 
sedang dalam menyusun rencana penyelesaian. Subjek kemampuan matematika tinggi dan subjek berkemampuan matematika sedang mampu menjabarkan cara atau langkah yang digunakan dan dapat menjelaskan secara lisan, berbeda dengan subjek berkemampuan matematika rendah yang tidak mampu menuliskan langkah dan tidak mampu melakukan manipulasi pada soal yang diberikan. Hal ini sejalan dengan penelitian Nafi'ah (2015) yang menyatakan bahwa siswa yang mampu melakukan manipulasi dapat dilihat dari cara siswa dalam menyelesaikan masalah. Penelitian ini sejalan dengan penelitian Nugraheni (2017) yang menyatakan subjek berkemampuan matematika tinggi dan sedang dapat melakukan manipulasi matematika karena dapat menjelaskan langkah penyelesaian yang digunakan. Sejalan dengan penelitian Azmi (2011) yang menyatakan bahwa hanya subjek berkemampuan tinggi dan sedang yang dapat memenuhi indikator melakukan manipulasi sedangkan untuk subjek berkemampuan rendah tidak memenuhi tidak mampu melakukan manipulasi karena kedua subjek yang memiliki kemampuan matematika tinggi dan sedang mampu menyelesaikan masalah yang diberikan dengan benar sedangkan subjek berkemampuan matematika rendah hanya menjawab dengan asal. Penelitian ini sejalan dengan penelitian Dewi (2011) menunjukkan bahwa hanya subjek berkemampuan matematika tinggi yang mampu memenuhi indikator melakukan manipulasi matematik dengan baik, sedangkan untuk subjek berkemampuan matematika sedang dan rendah tidak dapat memenuhi indikator kedua karena subjek mampu menyelesaikan dan menuliskan cara yang digunakan dengan baik, sedangkann subjek berkemampuan matematika rendah tidak dapat menuliskan secara legkap.

\section{Indikator Menarik Kesimpulan, Menyusun Bukti dan Memberikan Alasan}

Berdasarkan data analisis yang sudah dipaparkan sebelumnya bahwa subjek berkemampuan matematika tinggi dan rendah yaitu subjek berkemampuan matematika tinggi dan subjek berkemampuan matematika rendah tidak mampu membuat kesimpulan, menyusun bukti, dan memberikan alasan dalam menyelesaikan permasalahan yang diberikan. Berbeda dengan subjek berkemampuan matematika sedang yang mampu memberikan kesimpulan, bukti dan menuliskan alasan. Subjek berkemampuan matematika tinggi dan subjek berkemampuan matematika rendah tidak dapat menuliskan dengan lengkap kesimpulan untuk membuat rencana penyelesaian dan tidak dapat menyusun bukti dan memberikan alasan terhadap beberapa solusi dari permasalahan yang ada. Tetapi untuk subjek berkemampuan matematika sedang mampu menuliskan alasan dan bukti dengan baik terlihat pada langkah penyelesaian subjek berkemampuan matematika sedang yang mampu menuliskan langkah-langkah penyelesaian hingga selesai. Penelitian yang dilakukan Dewi (2011) yang menyatakan bahwa hanya subjek kemampuan matematika rendah tidak mampu menuliskan bukti dan kesimpulan sehingga tidak dapat memenuhi indikator. Penelitian yang dilakukan Nugraheni (2017) menyatakan bahwa siswa yang memiliki kemampuan matematika sedang dapat menarik kesimpulan, menyusun bukti, dan memberikan alasan dari langkah yang digunakan dalam menyelesaikan masalah. Penelitian yang lain yang sejalan ialah penelitian yang dilakukan oleh Melin 
(2015) yang menyataan subjek berkemampuan matematika sedang dapat memberikan alasan terhadap kebenaran solusi, sedangkan subjek kemampuan matematika rendah tidak dapat memberikan alasan atas kebenaran solusi.

\section{Indikator Menarik Kesimpulan atas Pernyataan}

Berdasarkan hasil analisis yang sudah dilakukan pada indikator ini subjek berkemampuan matematika tinggi dan subjek berkemampuan matematika rendah tidak mampu memberikan kesimpulan dalam menyelesaikan permasalahan yang diberikan. Berbeda dengan subjek berkemampuan matematika sedang mampu memenuhi indikator 4 dengan baik Hal ini dikarenakan subjek berkemampuan matematika tinggi dan subjek berkemampuan matematika rendah merasa kebingungan dalam mengerjakan sehingga subjek tidak mampu menarik kesimpulan, sedangkan untuk subjek berkemampuan matematika sedang mampu menarik kesimpulan secara tertulis maupun secara lisan saat diwawancara dengan baik. Sejalan dengan penelitian yang dilakukan oleh Melin (2015) yang menyatakan bahwa subjek berkemampuan matematika rendah tidak mampu memenuhi indikator menarik kesimpulan karena dalam membuat kesimpulan belum benar atau tidak sesuai dengan soal dan jawabannya, subjek berkemampuan matematika sedang mampu membuat kesimpulan berdasarkan soal dan jawaban yang diperolehnya. Penelitian ini sejalan dengan penelitian Nugraheni (2017) yang menyatakan bahwa subjek berkemampuan matematika sedang mampu memenuhi indikator keempat karena subjek kemampuan matematika sedang mampu menarik kesimpulan yang dapat dilihat dari langkah penyelesaian dan hasil pemfaktoran yang benar, sedangkan untuk subjek berkemampuan rendah tidak memenuhi indikator keempat karena subjek kemampuan matematika rendah dalam menarik kesimpulan atas pernyataan masih kurang tepat. Penelitian yang dilakukan oleh Sulistiawati (2018) menyatakan bahwa subjek yang memiliki kemampuan matematika rendah tidak dapat menarik kesimpulan apapun dengan alasan sudah lupa cara menyelesaikan soal yang telah diberikan.

\section{KESIMPULAN}

Berdasarkan hasil dan pembahasan yang dikemukakan pada bab sebelumnya, maka dapat disimpulkan sebagai berikut:

1. Kemampuan penalaran siswa yang memiliki kemampuan matematika tinggi mampu memenuhi indikator untuk dapat mengajukan dugaan, dan dapat melakukan manipulasi matematika, tetapi tidak dapat memenuhi indikator menarik kesimpulan, menyusun bukti, memberikan alasan dan menarik kesimpulan atas pernyataan.

2. Kemampuan penalaran siswa yang memiliki kemampuan matematika sedang mampu memenuhi semua indikator yaitu indikator mengajukan dugaan, melakukan manipulasi matematika, indikator menarik kesimpulan, menyusun bukti, memberikan alasan dan menarik kesimpulan atas pernyataan 
3. Kemampuan penalaran siswa yang memiliki kemampuan matematika rendah mampu memenuhi indikator untuk dapat mengajukan dugaan, tetapi tidak dapat memenuhi indikator manipulasi matematika, menarik kesimpulan, menyusun bukti, memberikan alasan dan indikator menarik kesimpulan atas pernyataan.

Saran yang dapat dikemukakan oleh peneliti adalah sebagai berikut:

1. Bagi Siswa

Hendaknya siswa meningkatkan kemampuan bernalarnya terkhusus dalam mata pelajaran matematika, dengan terus belajar dan dengan mengerjakan latihan-latihan pemecahan masalah matematika yang dapat mengembangkan kemampuan bernalar matematika.

2. Bagi Guru

Kemampuan penalaran siswa sangat berpengaruh terhadap pembelajaran matematika dalam menyelesaikan soal pemecahan masalah sehingga penting bagi guru untuk memperhatikan hal tersebut dalam pembelajaran matematika. Guru dapat mengembangkan pengajaran dan soal latihan pemecahan masalah untuk meningkatkan kemampuan penalaran siswa.

3. Bagi Peneliti lain

Penelitian selanjutnya diharapkan dapat lebih mengembangkan pengetahuan yang berkaitan dengan kemampuan penalaran dengan karakteristik yang berbeda dan materi yang berbeda.

\section{DAFTAR PUSTAKA}

Andayani, F \& Lathifah N. A. 2019. Analisis Kemampuan Pemecahan Masalah Siswa SMP Dalam Menyelesaiakan Soal Pada Materi Aritmatika Sosial. Jurnal Cendekia: Jurnal Pendidikan Matematika. Vol 3. No 1. Hal 1-10.

Depdiknas. 2006. Permendinas No 22 Tahun 2006 Tentang Stansar Isi. Jakarta. Depdiknas.

Hendriana, H. dkk. 2017. Hard Skills dan Soft Skills matematika siswa. Bandung. PT Refika Aditama.

Meicahyati. 2018. Meningkatkan Kemampuan Penalaran Matematik Siswa SMP Menggunakan Pendekatan Problem Possing Melalui Pembelajaran Kooperatif Tipe Jigsaw. Jurnal Cendekia: Jurnal Pendidikan Matematika. Vol 2. No 2. Hal 1-10.

Melin, K. 2015. Profil Kemampuan Penalaran Siswa Dalam Memecahkan Masalah Soal Cerita Barisan dan Deret Aritmatika di Kelas X SMA Negeri 2 Palu. Jurnal Pendidikan Matematika. Universitas Tadulako. Vol 4. No 2. Hal 178-188.

Pawesti, B. A. (2017). Kemampuan Penalaran Matematis Dalam Menyelesaikan Soal Garis Singgung Lingkaran Ditinjau dari Gaya Belajar pada Siswa Kelas VIII di SMP N 1 Nanggulan Tahun Ajaran 2016/2017. Skripsi. Universitas Sanata Dharma. Yogyakarta. Hal 144. 
Prasetyo, J, D. 2017. Pengembangan Perangkat Pembelajaran Matematika Berbasis Masalah Pada Materi Aritmetika Sosial Untuk Siswa Smp Kelas VII. Skripsi. Universitas Negeri Yogyakarta. Hal 4

Suciati D. 2015. Profil Kemampuan Penalaran Siswa Dalam Memecahkan Masalah Aritmetika Sosial. Jurnal Pendidikan Matematika. Jurnal Pendidikan Matematika STKIP PGRI Sidoarjo, Vol 3, No 1, Hal 46

Sugiyono. 2012. Metode Penelitian Pendidikan Pendekatan Kualitatif, Kualitatif, dan R\&D. Bandung. Alfabeta.

Suriasumantri, J. 2010. Filsafat Ilmu Sebuah Pengantar Populer. Jakarta. PT Penebaran Swadaya. Wardhani. 2008. Analisis SI dan SKL Mata Pelajaran Matematika SMP/MTs Untuk Optimalisasi Pencapaian Tujuan. Yogyakarta. Pusat Pengembangan Dan Pemberdayaan Pendidikan dan Tenaga Kependidikan Matematika.

Yenni, \& Aji, R. S. (2016). Analisis Kemampuan Penalaran Matematis Siswa Smp Melalui Model Pembelajaran Numbered Heads Together. Jurnal Prima. Vol 5 N o 2, Hal 78-80. 